\title{
Method Validation and Dissipation Behaviour of Dimethyl Disulphide (DMDS) in Cucumber and Soil by Gas Chromatography-Tandem Mass Spectrometry
}

\author{
Abdul Kaium ${ }^{1,2,+}{ }^{\mathbb{B}}$, Junli Cao ${ }^{1,3,+}$, Xingang Liu ${ }^{1, *}$, Jun $\mathrm{Xu}^{1}{ }^{1}$, Fengshou Dong ${ }^{1}$, Xiaohu Wu ${ }^{1}$ and \\ Yongquan Zheng ${ }^{1}$ \\ 1 State Key Laboratory for Biology of Plant Disease and Insect Pests, Institute of Plant Protection, \\ Chinese Academy of Agricultural Sciences, Beijing 100193, China; kaium.agrichemistry@gmail.com (A.K.); \\ cjlagriculture@163.com (J.C.); xujun1977927@163.com (J.X.); fsdong@ippcaas.cn (F.D.); \\ xhwu@ippcaas.cn (X.W.); yqzheng@ippcaas.cn (Y.Z.) \\ 2 Department of Agricultural Chemistry, Sher-e-Bangla Agricultural University, Dhaka 1207, Bangladesh \\ 3 College of Chemistry, Central China Normal University, Wuhan 430079, China \\ * Correspondence: liuxingang@caas.cn; Tel./Fax: +86-10-62815908 \\ + These authors contributed equally to this paper.
}

Received: 21 September 2019; Accepted: 10 November 2019; Published: 14 November 2019

\begin{abstract}
In this study, a useful analytical method was developed and validated for measuring the residues of dimethyl disulphide (DMDS) in cucumbers and soil by gas chromatography-tandem mass spectrometry (GC-MS/MS). The dissipation dynamics and residual levels of DMDS in cucumber and soil were also studied in Shandong, Jilin, and Hebei provinces by using this method. Dichloromethane was selected and used as the extraction solvent to extract the target pesticide from the soil and cucumber samples. The soil and cucumber samples were cleaned up by the combination of multiwalled carbon nanotubes (MWCNT) and biochar. The average recoveries of the DMDS in cucumbers and soil were in the range of $84-101.5 \%$, with relative standard deviations (RSD) of $0.7-4.9 \%$, when they spiked at 0.05 , 0.5 , and $5 \mathrm{mg} / \mathrm{kg}$ DMDS respectively. The limit of quantification (LOQ) of this method was $0.05 \mathrm{mg} / \mathrm{kg}$. First-order and second-order kinetic equations were used to fit dissipation data. Results show that the half-lives of DMDS in the soil at Shandong, Jilin, and Hebei were 1.63-4.47 days, 1.96-6.49 days, and 1.35-2.51 days, respectively. The final residues of DMDS were less than $0.05 \mathrm{mg} / \mathrm{kg}$ in cucumbers and $0.36 \mathrm{mg} / \mathrm{kg}$ in the soil. The dissipation rates of DMDS in different soils were different. The method provides a basis for the risk assessment of DMDS in cucumber and soil.
\end{abstract}

Keywords: dimethyl disulphide (DMDS); cucumber; soil; gas chromatography-mass spectrometry

\section{Introduction}

Soil-borne disease and pests are becoming a significant issue in vegetable production worldwide [1]. In the vegetable production system, chemical fumigants have been used to control soil-borne disease and pests for a long time [2]. Methyl bromide ( $\mathrm{MeBr}$ ) was the only chemical fumigant that was used extensively in the past 40 years to control soil-borne disease and pest in agriculture [3,4]. $\mathrm{MeBr}$ was phased out worldwide in 2015 due to its stratospheric ozone depletion potential [4,5]. As a substitute for MeBr [6,7], dimethyl disulphide (DMDS, see Figure 1)—a volatile sulfur compound that has zero ozone depletion potential-was first registered and applied in the United States as a plant pre-pest management soil fumigant [8]. Since 2001, DMDS has been one of the most experimented and discussed volatile chemical compounds for soil disinfestation in the US, EU, China, and the Mediterranean countries [9-13]. Nowadays, it has been widely used to protect vegetables all over the world. Several trials of DMDS efficiency have shown excellent control of broad-spectrum soil-borne 
pests like nematode, fungus, insects, and weeds [10,12,14-17]. For best performance, the fumigant must move across the soil profile and last an appropriately long time to ensure successful soil pest control [18,19]. Conkle et al. [20] reported that DMDS might need to be applied at a high dose to achieve higher efficacy due to its lower volatility and higher soil adsorption rate. However, soils with high fumigant concentrations can cause phytotoxicity, which usually results in low yields or even plant death. Therefore, it is necessary to establish an effective detection method to study the degradation dynamics and residual behavior of DMDS in soil and crops.

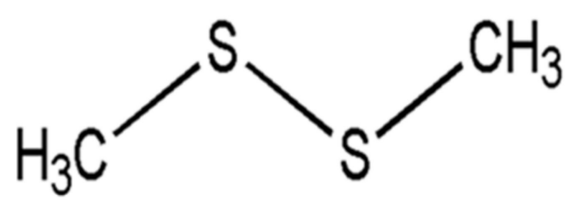

Figure 1. The chemical structure of dimethyl disulphide (DMDS).

There are some techniques for determining DMDS residues in the soil, including Fourier transform infrared spectroscopy (FTIR) [21], gas chromatography equipped with flame ionization detector (GC-FID) [22] and gas chromatography-mass spectrometry (GC-MS) [23]. However, to the authors' knowledge, there is no report of a method for the determination of DMDS residue in cucumber samples. Therefore, minimal data have been reported concerning the dissipation of DMDS in cucumber and soil under open field conditions in the different growing areas of China.

In this study, an efficient analytical method using gas chromatography coupled with tandem mass spectrometry was proposed to determine the DMDS residues in cucumber and soil. Moreover, the dissipation rate and final residue level of DMDS under open field conditions were studied in different growing areas of China. The residual dissipation and final residue of DMDS were determined to provide evaluation for the safe use of DMDS.

\section{Materials and Methods}

\subsection{Standards and Reagents}

DMDS (purity 99.6\%) was provided by French company Arkema. HPLC-grade ethyl acetate, cyclohexane, acetone, petroleum ether, and dichloromethane were bought from the Beijing Chemical Company (Beijing, China). Graphitized carbon black (GCB, 120-400 mesh), multi-walled carbon nanotubes (MWCNT, 20-30 $\mu \mathrm{m}$ ) were purchased from Bonna-Agela Technologies (Tianjin, China) and Biochar (200-400 mesh) was from Panzhihua Xiyu Biological Technology Co. Ltd. (Panzhihua, China). The standard stock solutions of DMDS were prepared in pure dichloromethane. Standard working solutions of $0.05,0.1,0.2,0.5,1,2$ and $5 \mathrm{mg} / \mathrm{L}$ were prepared by serial diluting from the stock solution. The matrix-matched standard solutions were prepared $(0.05,0.1,0.5,1,2$ and $5 \mathrm{mg} / \mathrm{L})$ by adding a blank matrix (cucumber and soil) to each serially diluted standard solution. All solutions were stored in a freezer at $-20^{\circ} \mathrm{C}$, ready for use.

\subsection{Field Study}

The cucumber field experiments were conducted in Shandong, Jilin, and Hebei province of China from September 2015 to October 2016. The atmospheric and soil physicochemical parameters of these three experimental sites are listed in Table 1 . According to the pesticide residue standard requirement test, each treatment consisted of three replicates and every plot with an area of $3 \times 5 \mathrm{~m}\left(15 \mathrm{~m}^{2}\right)$ [24]. For the dissipation studies, $99.6 \%$ pure DMDS was applied once to the cucumber field soils by syringe with a dosage $90 \mathrm{~g} / \mathrm{m}^{2} 1.5$ times than the recommended dosage [8]. The soils were covered with a protective film after the application of DMDS. Cucumber samples (approximately $500 \mathrm{~g}$ ) were collected from each plot after spraying on days $0(2,4,8,12 \mathrm{~h}), 1,3,5,7,14,21,28$ days, respectively, while soil samples (0-15 cm depth, approximately $500 \mathrm{~g})$ were randomly collected at $0(2,4,8,12 \mathrm{~h}), 1,3,5,7,14$, 
21, 28 days respectively. All the collected samples were stored in a freezer at $-20^{\circ} \mathrm{C}$ until extraction. For the final residue experiment, DMDS was applied at $60 \mathrm{~g} / \mathrm{m}^{2}$ and $90 \mathrm{~g} / \mathrm{m}^{2}$ in each experimental cucumber field. Each dosage level was designed to be applied once before seed sowing. Therefore, cucumber and soils (0-15 cm depth) samples were collected at intervals of $0,1,2,3,5$ and 7 days after cucumber maturation. All the samples were transported in labeled polythene bags and stored at $-20{ }^{\circ} \mathrm{C}$ for further analysis.

Table 1. Atmospheric and soil physicochemical parameters of three experimental field sites.

\begin{tabular}{ccccccc}
\hline $\begin{array}{c}\text { Experimental } \\
\text { Sites }\end{array}$ & Climate & $\begin{array}{c}\text { Average Annual } \\
\text { Rainfall }(\mathbf{m m})\end{array}$ & $\begin{array}{c}\text { Average Annual } \\
\text { Temperature }\left({ }^{\circ} \mathbf{C}\right)\end{array}$ & Soil Type & $\begin{array}{c}\text { Organic-Matter } \\
\mathbf{( \% )}\end{array}$ & Soil pH \\
\hline Shandong & $\begin{array}{c}\text { semi-humid } \\
\text { monsoon }\end{array}$ & $900-750$ & 13 & Brown soil & 2 & 7.15 \\
Jilin & $\begin{array}{c}\text { temperate } \\
\text { monsoon } \\
\text { temperate } \\
\text { monsoon }\end{array}$ & $400-600$ & 17 & Sandy loam & 3.40 & 7.3 \\
\hline
\end{tabular}

\subsection{Sample Preparation Procedure}

Cucumber and soil samples were blended separately by a homogenizer, and $5 \mathrm{~g}$ of each sample was transferred to a $20 \mathrm{~mL}$ headspace vials, then added $5 \mathrm{~mL}$ dichloromethane, $3 \mathrm{~g}$ sodium chloride and purification agents ( $25 \mathrm{mg}$ MWCNT $+50 \mathrm{mg}$ Biochar) to each vial. These vials were sealed with a Teflon film aluminium cover and placed in a water bath with static $80^{\circ} \mathrm{C}$ temperatures for $30 \mathrm{~min}$. After cooling, a $1 \mathrm{~mL}$ lower layer of dichloromethane extract was taken with a syringe, then filtered through a $0.22 \mu \mathrm{m}$ PTFE filter and transferred into a glass vial for GC-MS/MS analysis.

\subsection{Instrumental and Analytical Conditions}

A Varian 450GC-300MS was used to detect and analyze the samples. The chromatographic separation was performed on a DB-5MS analytical column $(30 \mathrm{~m} \times 0.25 \mathrm{~mm}$, i.d. $\times 0.25 \mu \mathrm{m})$. Helium $(99.9999 \%)$ was used as the carrier gas at the flow rate of $1.0 \mathrm{~mL} / \mathrm{min}$. The temperature of the injector port was $230^{\circ} \mathrm{C}$, and a volume of $5 \mu \mathrm{L}$ was injected in the splitless mode. The samples were analyzed using the oven temperature program: Initial temperatures of $40{ }^{\circ} \mathrm{C}$ (hold for $3 \mathrm{~min}$ ), then ramped up to $50{ }^{\circ} \mathrm{C}$ at $5{ }^{\circ} \mathrm{C} / \mathrm{min}$ (hold for $7 \mathrm{~min}$ ). The ion source and transfer line temperatures were set at $230^{\circ} \mathrm{C}$. The mass spectrometer was operated in electron ionisation mode at $70 \mathrm{eV}$. Detection was performed in the $79 \mathrm{~m} / \mathrm{z}, 61 \mathrm{~m} / \mathrm{z}$, and $45 \mathrm{~m} / \mathrm{z}$ selected ion monitoring (SIM) mode for the quantitative and qualitative analysis.

\subsection{Method Validation}

According to European Union guidelines (SANTE/11813/2017) [25], the method was validated on parameters of selectivity, linearity, accuracy, precision, the limit of detection (LOD) and limit of quantification (LOQ). Linearity was determined by constructing calibration curves using standard solutions of different concentrations $(0.05-5 \mathrm{mg} / \mathrm{kg})$. The LOD was calculated as the lowest concentration giving a response three times the standard deviation of the baseline noise. The LOQ was calculated as the lowest spiked level during the recovery experiments that provide satisfactory values of recovery $(70-120 \%$ ), and relative standard deviation (RSD) $\leq 20 \%$. Recovery and repeatability (RSD) experiments were carried out to investigate the accuracy and precision of the method at three levels of fortification $0.05,0.5$ and $5 \mathrm{mg} / \mathrm{kg}$ DMDS in cucumber and soil replicated five times alongside a control. In this method, the accuracy was determined by average recovery assays obtained according to the standard European Union guidelines, and the precision was determined by the relative standard deviation (RSD). 


\subsection{Statistical Analysis}

The first-order kinetics model and the second-order kinetics model were used to describe DMDS dissipation. The degradation rate constants and half-lives were calculated using equations $C_{t}=C_{0} e^{-k t}$ and $C_{t}=C_{0} /\left(1+C_{0} \times k t\right)$, where $C_{t}$ represents the concentration of DMDS residue at the time of $t$, $\mathrm{C}_{0}$ represents the initial concentration, and $\mathrm{k}$ is the dissipation degradation rate constant (days -1 ). $\mathrm{T}_{1 / 2}$ represents the time when the residual is half of the initial concentration. All the calculations were made by Microsoft Office Excel 2010 software.

\section{Results and Discussion}

\subsection{Validation of the Method}

\subsubsection{Matrix Effects, Linearity, LODs and LOQs}

The proposed method was applied to the blank samples of different matrices to evaluate its specificity. The calibration curves for DMDS (from 50 to $5000 \mathrm{mg} / \mathrm{kg}$ ) in dichloromethane and different matrices were obtained, and the linear regression results were summarized in Table 2 . The results showed that the cucumber matrix significantly suppressed the instrument's response, and no significant suppression or improvement of DMDS response was observed in the soil matrix. The response of standard solution calibration curves was compared to matrix-matched calibration curves using a two-tailed paired $t$-test with a probability of $95 \%$. The $P$ values imply that the data between pure solvent and cucumber are significantly different $(P<0.05)$ and have no significant difference $(P>0.05)$ with soil. Therefore, matrix-matched standards were used to eliminate matrix effects.

Table 2. Calibration equation and linear regression parameters of calibration curves of DMDS in solvent and matrices.

\begin{tabular}{cccccc}
\hline Matrix & Calibration Equation & Coefficient $\left(\boldsymbol{R}^{\mathbf{2}}\right)$ & $\boldsymbol{P}$ Value & $\begin{array}{c}\text { LOD } \\
(\mathbf{m g} / \mathbf{k g})\end{array}$ & $\begin{array}{c}\text { LOQ } \\
(\mathbf{m g} / \mathbf{k g})\end{array}$ \\
\hline Dichloromethane & $y=8656123 x+719091$ & 0.9996 & - & 0.012 & 0.05 \\
Cucumber & $y=6808925 x-936245$ & 0.9956 & 0.041 & 0.015 & 0.05 \\
Soil & $y=7811030 x+1803515$ & 0.9953 & 0.49 & 0.015 & 0.05 \\
\hline
\end{tabular}

DMDS was detected at the retention time of $5.0 \mathrm{~min}$ (Figure 2). The linearity, LOD, and LOQ were obtained using the peak areas of the product ion obtained by GC-MS analysis using the SIM mode. The results showed that the linearity is excellent, with a regression correlation coefficient of $R^{2}=0.9996$. The LOD and LOQ were determined as 0.015 and $0.05 \mathrm{mg} / \mathrm{kg}$. 


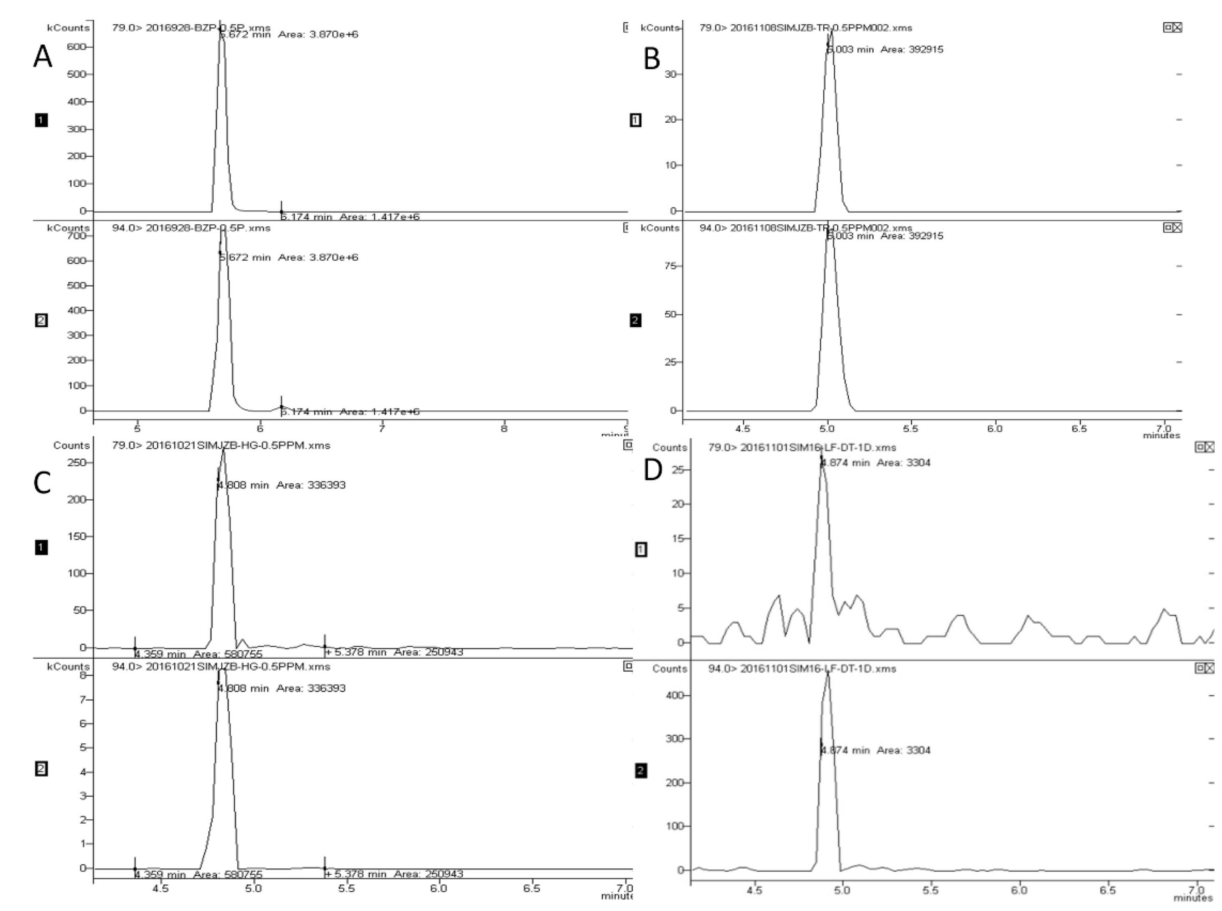

Figure 2. Chromatograms of the (A) DMDS standard, (B) soil spiked at $0.5 \mathrm{mg} / \mathrm{kg}$, (C) cucumber spiked at $0.5 \mathrm{mg} / \mathrm{kg}$, (D) DMDS residue in soil on the 1st day after application in the Hebei location.

\subsubsection{Optimization of the Extraction Method}

In this work, three extraction methods in brown soil were compared: Shock extraction, water bath, and ultrasound extraction for $20 \mathrm{~min}$. The results in Figure 3 showed that the water bath offered higher recoveries $(118.2 \%)$ than ultrasound extraction $(60.9 \%)$ and shock extraction $(49.2 \%)$. For the residue determination method, recoveries in the range of $70 \%$ to $120 \%$ are considered acceptable. Therefore, the water bath was chosen as the extraction method. Five organic solvents (acetone, ethyl acetate, cyclohexane, petroleum ether, dichloromethane) were then compared to the solvent with the highest extraction efficiency. As shown in Figure 3, the recovery of DMDS extracted with dichloromethane $(107.7 \%)$ was higher than acetone $(12.8 \%)$, ethyl acetate $(42.2 \%)$, cyclohexane $(7.4 \%)$ and petroleum ether $(85.4 \%)$. Therefore, dichloromethane was selected as the extractant for the following experiments. However, different water bath times and temperatures could affect the recoveries. This is because short time makes extraction insufficient while delaying time, and whether the temperature is too high or too low will reduce the extraction efficiency. As shown in Figure 3, when the temperature was $80^{\circ} \mathrm{C}$, and the bath time was $30 \mathrm{~min}$ and $80 \mathrm{~min}$, the recoveries were $95.9 \%$ and $101.1 \%$. In view of the efficiency of the experiment, $80^{\circ} \mathrm{C}$ water bath for $30 \mathrm{~min}$ was chosen as the extraction technique for this method.

In order to achieve a satisfactory clean-up effect, three types of sorbent, biochar (50 mg) + MWCNT $(25 \mathrm{mg})$, biochar $(50 \mathrm{mg})+\mathrm{GCB}(25 \mathrm{mg})$ and biochar $(75 \mathrm{mg})$ were evaluated in this work to investigate the impacts on recoveries in cucumber and soil matrices. GCB is mainly used to remove pigments such as chlorophyll and carotenoids [26]. MWCNT has been reported as a new type of purification material with a better purification effect for its larger specific surface area [27]. Biochar has commonly been used in water and soil cleanup and toxic material remediation from the environment [28]. However, on the other site, biochar has a very high affinity and capacity to sorbing organic compounds [29]. In this experiment, biochar was for the first time used as a cleanup sorbent for pesticide residue extraction from the soil and cucumber samples. The results show that when biochar with a certain proportion of GCB was used as a cleanup sorbent in soil matrices, the recoveries of DMDS were relatively low $(78.5 \%)$, which may mean that the interfering impurity was not completely eliminated in this matrix, but that 
the biochar with MWCNT gave a higher recovery (96.5\%). Finally, the biochar (50 mg) + MWCNT $(25 \mathrm{mg})$ was selected as the final cleanup sorbent to clean up impurities in soil and cucumber matrices.
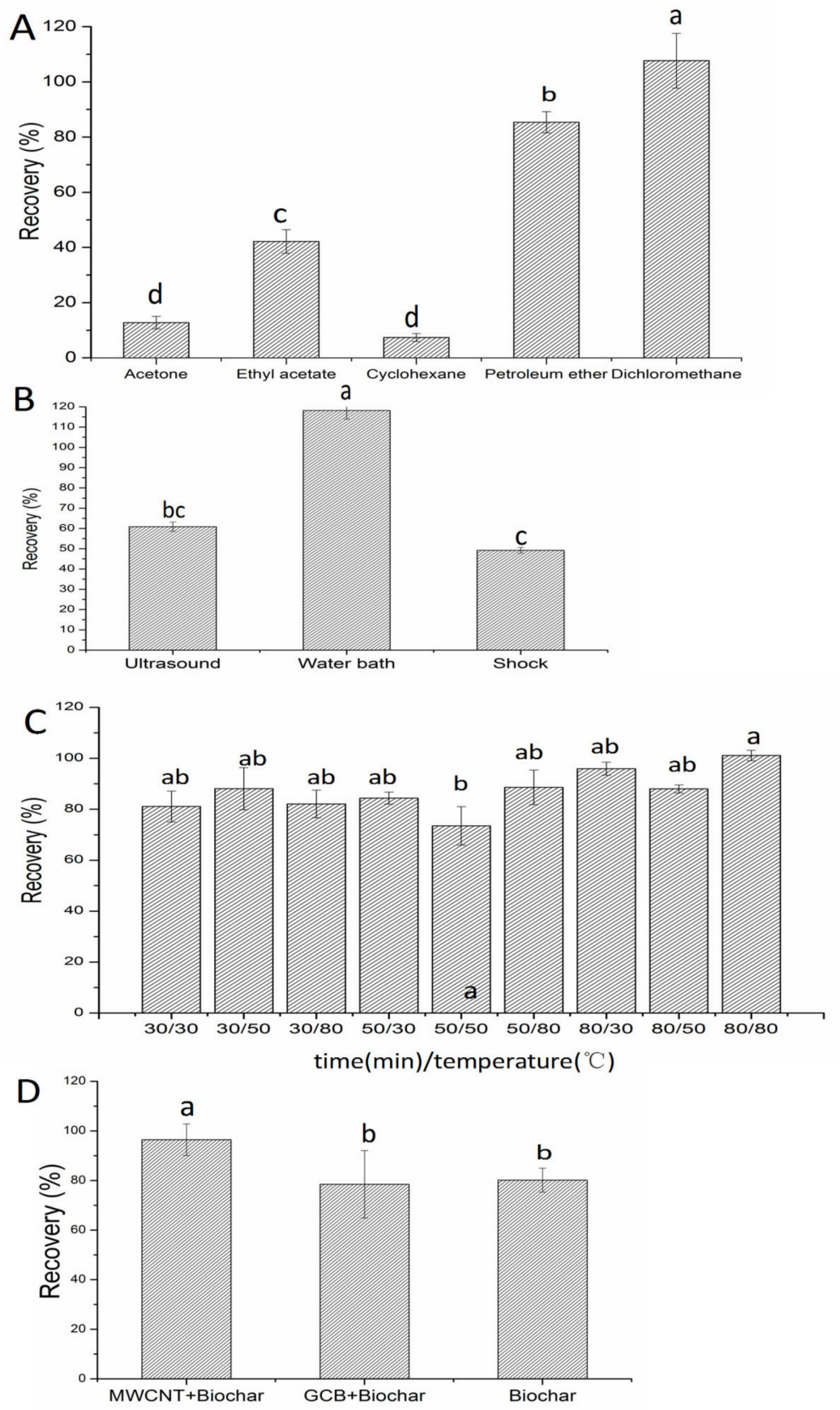

Figure 3. Comparison of recoveries of DMDS in soil samples $(0.5 \mathrm{mg} / \mathrm{kg})$ with (A) different extraction solvents, (B) different extraction methods, (C) different water bath time and temperature, (D) different cleanup sorbents.

\subsubsection{Accuracy and Precision}

The accuracy and precision of the measurements were expressed in terms of recoveries and RSDs at different spiked levels $(0.05,0.5$ and $5 \mathrm{mg} / \mathrm{kg})$ in cucumber and soil. DMDS recoveries for cucumber and soil ranged between $84.0-101.5 \%$ and $84.3-98.7 \%$, respectively, with RSDs between $0.5-6.5 \%$ and $0.7-4.9 \%$ (Table 3 ). The results have confirmed that the method is sufficiently reliable for DMDS residue analysis in this experiment [30]. 
Table 3. Average recoveries and relative standard deviations (RSD) of cucumber and soil samples $(n=5)$.

\begin{tabular}{|c|c|c|c|c|c|c|}
\hline \multirow[b]{2}{*}{ Matrix } & \multicolumn{2}{|c|}{$\begin{array}{c}\text { Spiking } \\
0.05 \mathrm{mg} / \mathrm{kg}\end{array}$} & \multicolumn{2}{|c|}{$\begin{array}{l}\text { Spiking } \\
0.5 \mathrm{mg} / \mathrm{kg}\end{array}$} & \multicolumn{2}{|c|}{$\begin{array}{l}\text { Spiking } \\
5 \mathrm{mg} / \mathrm{kg}\end{array}$} \\
\hline & $\begin{array}{c}\text { Mean } \\
\text { Recovery } \\
(\%)\end{array}$ & $\begin{array}{c}\text { RSD } \\
(\%)\end{array}$ & $\begin{array}{c}\text { Mean } \\
\text { Recovery } \\
(\%)\end{array}$ & $\begin{array}{c}\text { RSD } \\
(\%)\end{array}$ & $\begin{array}{c}\text { Mean } \\
\text { Recovery } \\
(\%)\end{array}$ & $\begin{array}{l}\text { RSD } \\
(\%)\end{array}$ \\
\hline Cucumber & 83.98 & 6.5 & 90.28 & 0.5 & 101.51 & 3.8 \\
\hline Soil & 74.07 & 4.9 & 84.33 & 0.7 & 98.69 & 4.8 \\
\hline
\end{tabular}

\subsection{Dissipation Dynamics}

The first-order kinetic equation is commonly used to describe pesticide dissipation dynamics. However, the first-order equation does not take into consideration the environmental effects of these dissipation studies, which are supported by Gottschalk et al. [31]. In this study, the first-order kinetic equation and the second-order kinetic equation both were used to fit the dynamic data simultaneously.

\subsubsection{Dissipation of DMDS in Soil}

The dynamics of dissipation and half-life of DMDS in soil are presented in Figure 4 and Table 4 . In order to interpret the dissipation of the DMDS in soil, other regression models were adapted to total mass, although pesticide dissipation in the soil is often assumed to be a first-order reaction [32,33]. $\mathrm{R}^{2}$ was used for comparison of model fits (Table 4). Initial DMDS concentrations in soil were $0.89 \mathrm{mg} / \mathrm{kg}$. According to first-order kinetic equation data, the half-life degradation of DMDS in soil was 4.47, 3.07, and 2.10 days for 2015 in the provinces of Shandong, Jilin, and Hebei, while the half-life was 2.49, 6.49 and 1.35 days for 2016. According to the second-order kinetic equation for 2015 and 2016, the DMDS dissipated with a half-life of 3.70-1.63 days, 1.96-5.56 days, and 1.55-2.51 days in Shandong, Jilin, and Hebei, respectively. The second-order equation also supports the first order dissipation regression equation.
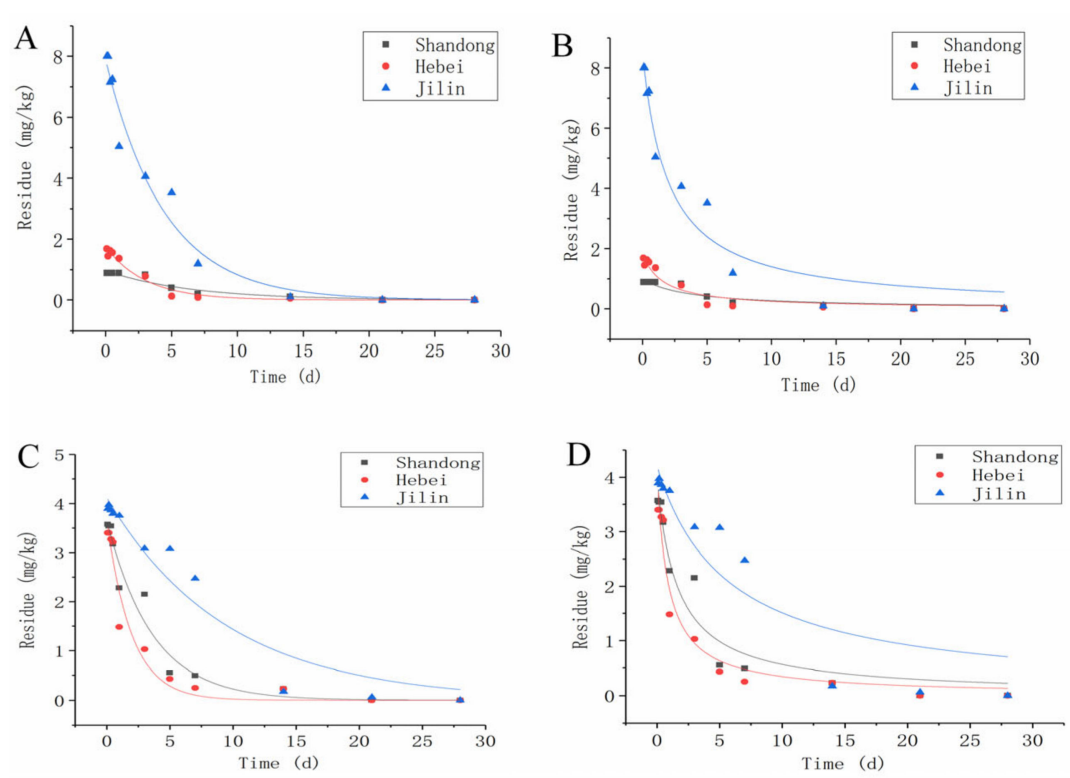

Figure 4. Dissipation dynamics of DMDS in the soil of three different experimental sites of China: (A) according to the first-order kinetic equation in 2015, (B) according to the second-order kinetic equation in 2015, (C) according to the first-order kinetic equation in 2016, (D) according to the second-order kinetic equation in 2016. 
Table 4. The regression equation and half-life for DMDS dissipated in soil.

\begin{tabular}{|c|c|c|c|c|c|c|c|}
\hline \multirow{2}{*}{$\begin{array}{l}\text { Time } \\
\text { (year) }\end{array}$} & \multirow{2}{*}{ Locality } & \multicolumn{3}{|c|}{ First-Order Kinetic Equation } & \multicolumn{3}{|c|}{ Second-Order Kinetic Equation } \\
\hline & & $\begin{array}{c}\text { Regression } \\
\text { Equation }\end{array}$ & $\begin{array}{c}\text { Coefficient } \\
\left(\mathbf{R}^{2}\right)\end{array}$ & $\begin{array}{l}\text { Half-Life } \\
\text { (day) }\end{array}$ & Regression Equation & $\begin{array}{l}\text { Coefficient } \\
\left(\mathbf{R}^{2}\right)\end{array}$ & $\begin{array}{l}\text { Half-Life } \\
\text { (day) }\end{array}$ \\
\hline \multirow{3}{*}{2015} & Shandong & $y=0.96249 e^{-0.15433 x}$ & 0.9498 & 4.47 & $\mathrm{y}=0.98888 /(1+0.2702 \mathrm{x})$ & 0.8943 & 3.70 \\
\hline & Jilin & $y=7.86281 e^{-0.22474 x}$ & 0.9720 & 3.07 & $y=8.5319 /(1+0.5096 x)$ & 0.958 & 1.96 \\
\hline & Hebei & $y=1.74864 e^{-0.32911 x}$ & 0.9757 & 2.10 & $y=1.8531 /(1+0.6463 x)$ & 0.9334 & 1.55 \\
\hline \multirow{3}{*}{2016} & Shandong & $y=3.64191 e^{-0.27719 x}$ & 0.9628 & 2.49 & $\mathrm{y}=3.9897 /(1+0.614 \mathrm{x})$ & 0.9441 & 1.63 \\
\hline & Jilin & $\mathrm{y}=4.1209 \mathrm{e}^{-0.10624 \mathrm{x}}$ & 0.9430 & 6.49 & $\mathrm{y}=4.20337 /(1+0.1799 \mathrm{x})$ & 0.8679 & 5.56 \\
\hline & Hebei & $y=3.66312 e^{-0.51003 x}$ & 0.9618 & 1.35 & $\mathrm{y}=4.05637 /(1+0.3984 \mathrm{x})$ & 0.9604 & 2.51 \\
\hline
\end{tabular}

Figure 4 shows the residue of DMDS in soil over the 2015 and 2016 test period in three different provinces in China. The curves of DMDS residue degradation dynamics in Shandong, Jilin and Hebei soil also had good comparability in 2 years and could be calculated by both the first-order kinetic equation and second-order kinetic equation. The results showed that the residue of DMDS was quickly dissipated in cucumber field soil. As expected, gradual and continuous degradation of the DMDS residues in the cucumber fields was observed, depending on the time after application. In the first 14 days after application, a rapid decrease in the amount of DMDS residues occurred and dissipated more than $90 \%$ after 14 days. DMDS dissipates faster in Hebei, is intermediate in Jilin and is slowest in Shandong because environmental and soil physio-chemical characteristics are different in Shandong, Jilin, and Hebei. It is reported that pesticide dissipation was a complex process depending on various environmental and soil physiochemical factors such as rainfall, temperature, relative humidity, soil organic matter, and soil $\mathrm{pH}$ [34].

\subsubsection{Dissipation of DMDS in Cucumber}

The dissipation study is an important part and would be useful for the proper and safe use of pesticides. A modified GC-MS/MS method was developed and used in this experiment to detect DMDS residues in samples collected from the provinces of Shandong, Jilin, and Hebei from September 2015 to October 2016 to investigate dissipation kinetics. We found a total of less than $0.05 \mathrm{mg} / \mathrm{kg}$ DMDS residue in cucumber samples collected after DMDS application, which is about less than DMDS LOQ in this method, so no further dissipation studies are required.

\subsubsection{The Final Residue of DMDS in Cucumber and Soil}

For cucumbers, the final residue of DMDS was $<0.05 \mathrm{mg} / \mathrm{kg}$, and for soil, the final residue was less than $0.36 \mathrm{mg} / \mathrm{kg}$. In this experiment, the residue of DMDS was $<0.05 \mathrm{mg} / \mathrm{kg}$ before the cucumber matured. The maximum residue limit (MRL) of DMDS in cucumber has not been established in China, the EU, the UK, and Japan. This study can provide basic data for the proposed DMDS MRL.

\section{Conclusions}

The GC-MS/MS residue analytical method has been validated and used for the determination of DMDS residues in cucumber and soil samples. By using this method, the experiment results showed that DMDS was susceptible to dissipate with half-lives ranging from 1.35 to 6.49 days in soil under the field ecosystem. The dissipation rates vary between the experimental sites of Shandong, Jilin, and Hebei, suggesting that dissipation of DMDS depends on environmental and soil physiochemical factors. The results showed that DMDS decreased very rapidly in open field conditions and finally dissipated over $90 \%$ within 14 days of application. The final residues of DMDS in soil and cucumber were 0.36 and $<0.05 \mathrm{mg} / \mathrm{kg}$, respectively, which is much lower than DMDS LOQ. These results showed that cucumbers could be safe when applied at the recommended dosage and suggested that the maximum residue limit of DMDS in cucumber is $0.05 \mathrm{mg} / \mathrm{kg}$. 
Author Contributions: Conceptualization, Y.Z. and X.L.; performed the experiments, A.K. and J.C.; formal analysis, J.X., F.D., and X.W.; writing-original draft preparation, A.K. and J.C.; writing-review and editing, J.X., F.D., and X.W.; supervision, X.L.; project administration, Y.Z.; funding acquisition, X.L.

Funding: This work was supported by the Institute of Plant Protection of the Chinese Academy of Agricultural Sciences (No. 201503107).

Acknowledgments: The authors would like to thank Mingfeng $\mathrm{Hu}$ at the Institute of Plant Protection for method development and validation work. Abdul Kaium also would like to thank the Bangabandhu Science and Technology Fellowship Trust, Ministry of Science and Technology of Bangladesh for the grant for his Ph.D. fellowship.

Conflicts of Interest: The authors declare no conflict of interest.

\section{References}

1. Singh, B.; Gupta, A. Monitoring of Pesticide Residues in Different Sources of Drinking Water of Jaipur, India. Bull. Environ. Contam. Toxicol. 2002, 69, 49-53. [CrossRef] [PubMed]

2. Triky-Dotan, S.; Westerdahl, B.; Martin, F.N.; Subbarao, K.; Koike, S.T.; Ajwa, H.A. Fumigant Dosages below Maximum Label Rate Control Some Soilborne Pathogens. Calif. Agric. 2016, 70, 130-136. [CrossRef]

3. Taylor, R. Facing the Future without Methyl Bromide-Are Alternatives Available to This Versatile Fumigant? Phytoparasitica 2001, 29,3-6. [CrossRef]

4. UNEP. Report of the Methyl Bromide Technical Options Committee; UNEP: Nairobi, Kenya, 2014.

5. Rosskopf, E.N.; Chellemi, D.O.; Kokalis-Burelle, N.; Church, G.T. Alternatives to Methyl Bromide: A Florida Perspective. Plant Health Prog. 2005, 6, 19. [CrossRef]

6. Fritsch, J. Dimethyl Disulfide as a New Chemical Potential Alternative to Methyl Bromide in Soil Disinfestation in France. Acta Hortic. 2005, 698, 71-76. [CrossRef]

7. Coosemans, J. Dimethyl Disulphide (DMDS): A Potential Novel Nematicide and Soil Disinfectant. Acta Hortic. 2005, 698, 57-64. [CrossRef]

8. U.S. Environmental Protection Agency. Pesticide Fact Sheet Name of Chemical: Dimethyl Disulfide Reason for Issuance: New Chemical; U.S. Environmental Protection Agency: Washington, DC, USA, 2010.

9. Cebolla, V.; Llobell, D.; Oliver, A.; Valero, L.M.; Torro, F.; Hernandez, A. The emulsifiable formulations of dimethyldisulfide (DMDS) and its mixtures with chloropicrin as alternatives to methyl bromide. In Acta Horticulturae; International Society for Horticultural Science: Leuven, Belgium, 2010; Volume 883, pp. 163-170. [CrossRef]

10. Zanón, M.J.; Gutiérrez, L.A.; Myrta, A. Spanish Experiences with Dimethyl Disulfide (DMDS) on the Control of Root-Knot Nematodes, Meloidogyne Spp., in Fruiting Vegetables in Protected Crops. Acta Hortic. 2014, 1044, 421-425. [CrossRef]

11. Heller, J.J.; Sunder, P.; Charles, P.; Pommier, J.J.; Fritsch, J. Dimethyl Disulfide, a New Alternative to Existing Fumigants on Strawberries in France and Italy. Acta Hortic. 2009, 842, 953-956. [CrossRef]

12. Myrta, A.; Santori, A.; Zanón, M.J.; Tsimboukis, N.; De Vries, R.; De Tommaso, N. Effectiveness of dimethyl disulfide (DMDS) for management of root-knot nematode in protected tomatoes in Southern Europe. In Acta Horticulturae; International Society for Horticultural Science: Leuven, Belgium, 2018; Volume 1207, pp. 123-127. [CrossRef]

13. Mao, L.; Yan, D.; Wang, Q.; Li, Y.; Ouyang, C.; Liu, P.; Shen, J.; Guo, M.; Cao, A. Evaluation of the Combination of Dimethyl Disulfide and Dazomet as an Efficient Methyl Bromide Alternative for Cucumber Production in China. J. Agric. Food Chem. 2014, 62, 4864-4869. [CrossRef]

14. Arnault, I.; Fleurance, C.; Vey, F.; Fretay, G.D.; Auger, J. Use of Alliaceae Residues to Control Soil-Borne Pathogens. Ind. Crop. Prod. 2013, 49, 265-272. [CrossRef]

15. Gilardi, G.; Gullino, M.L.; Garibaldi, A. Soil Disinfestation with Dimethyl Disulfide for Management of Fusarium Wilt on Lettuce in Italy. J. Plant Dis. Prot. 2017, 124, 361-370. [CrossRef]

16. Leocata, S.; Pirruccio, G.; Myrta, A.; Medico, E.; Greco, N. Dimethyl Disulfide (DMDS): A New Soil Fumigant to Control Root-Knot Nematodes, Meloidogyne Spp., in Protected Crops in Sicily, Italy. Acta Hortic. 2014, 1044, 415-420. [CrossRef]

17. Gómez-Tenorio, M.A.; Tello, J.C.; Zanón, M.J.; de Cara, M. Soil Disinfestation with Dimethyl Disulfide (DMDS) to Control Meloidogyne and Fusarium Oxysporum f. Sp. Radicis-Lycopersici in a Tomato Greenhouse. Crop Prot. 2018, 112, 133-140. [CrossRef] 
18. Gamliel, A.; Triky-Dotan, S. Accelerated degradation of soil fumigants: Occurrence and agricultural consequences. In Recent Developments in Management of Plant Diseases; Springer Netherlands: Dordrecht, The Netherlands, 2010; pp. 311-328. [CrossRef]

19. Ou, L.T.; Thomas, J.E.; Allen, L.H.; McCormack, L.A.; Vu, J.C.; Dickson, D.W. Effects of Application Methods and Plastic Covers on Distribution of Cis- and Trans-1,3-Dichloropropene and Chloropicrin in Root Zone. J. Nematol. 2005, 37, 483-488.

20. Conkle, J.L.; Cabrera, J.A.; Thomas, J.E.; Wang, D.; Gan, J. Effects of $\mathrm{CO}_{2}$ Dissolution on Phase Distribution and Degradation of Dimethyl Disulfide in Soils under Grape Production. Pest Manag. Sci. 2016, 72, 349-353. [CrossRef]

21. Lv, L.; Zhang, J.; Huang, C.; Lei, Z.; Chen, B. Adsorptive Separation of Dimethyl Disulfide from Liquefied Petroleum Gas by Different Zeolites and Selectivity Study via FT-IR. Sep. Purif. Technol. 2014, 125, 247-255. [CrossRef]

22. Perraud, V.; Meinardi, S.; Blake, D.R.; Finlayson-Pitts, B.J. Challenges Associated with the Sampling and Analysis of Organosulfur Compounds in Air Using Real-Time PTR-ToF-MS and Offline GC-FID. Atmos. Meas. Tech. 2016, 9, 1325-1340. [CrossRef]

23. Han, D.; Wang, Q.; Liu, P.; Fang, W.; Yan, D.; Cao, A. Dimethyl Disulphide Residue Analysis and Degradation Kinetics Determination in Soil Using Gas Chromatography-Mass Spectrometry. Int. J. Environ. Anal. Chem. 2016, 96, 694-704. [CrossRef]

24. FAO. Guidelines on Efficacy Data for the Registration of Pesticides; FAO: Rome, Italy, 1985.

25. EC (EUROPEAN COMMISSION). SANTE/11813/2017. Guidance Document on Analytical Quality Control and Method Validation Procedures for Pesticide Residues and Analysis in Food and Feed. EC (EUROPEAN COMMISSION). Available online: https://doi.org/10.13140/RG.2.2.33021.77283 (accessed on 21 November 2017).

26. Anastassiades, M.; Lehotay, S.J. Fast and Easy Multiresidue Method Employing Acetonitrile Extraction_Partitioning and "Dispersive Solid-Phase Extraction" for the Determination of Pesticide Residues in Produce. J. AOCA Int. 2003, 86, 412-431.

27. Zhao, P.; Wang, L.; Zhou, L.; Zhang, F.; Kang, S.; Pan, C. Multi-Walled Carbon Nanotubes as Alternative Reversed-Dispersive Solid Phase Extraction Materials in Pesticide Multi-Residue Analysis with QuEChERS Method. J. Chromatogr. A 2012, 1225, 17-25. [CrossRef]

28. Xie, T.; Reddy, K.R.; Wang, C.; Yargicoglu, E.; Spokas, K. Characteristics and Applications of Biochar for Environmental Remediation: A Review. Crit. Rev. Environ. Sci. Technol. 2015, 45, 939-969. [CrossRef]

29. Smernik, R.J. Biochar and sorption of organic compounds. In Biochar for Environmental Management: Science and Technology, 1st ed.; Lehmann, J., Joseph, S., Eds.; Taylor and Francis: London, UK, 2012; pp. $289-300$. [CrossRef]

30. Salazar, J.D. Review of the Statistical Procedures Currently in Use for the Calculation of Maximum Residue Limits. Outlooks Pest Manag. 2011, 22, 74-76. [CrossRef]

31. Gottschalk, F.; Sun, T.; Nowack, B. Environmental Concentrations of Engineered Nanomaterials: Review of Modeling and Analytical Studies. Environ. Pollut. 2013, 181, 287-300. [CrossRef] [PubMed]

32. Pennell, K.D.; Hornsby, A.G.; Jessup, R.E.; Rao, P.S.C. Evaluation of Five Simulation Models for Predicting Aldicarb and Bromide Behavior Under Field Conditions. Water Resour. Res. 1990, 26, 2679-2693. [CrossRef]

33. Weed, D.A.J.; Kanwar, R.S.; Stoltenberg, D.E.; Pfeiffer, R.L. Dissipation and Distribution of Herbicides in the Soil Profile. J. Environ. Qual. 1995, 24, 68-79. [CrossRef]

34. Racke, K.D.; Skidmore, M.W.; Hamilton, D.J.; Unsworth, J.B.; Miyamoto, J.; Cohen, S.Z.; Holland, P.T. Pesticide Fate in Tropical Soils. Pure Appl. Chem. 1997, 69, 1349-1371. [CrossRef]

(C) 2019 by the authors. Licensee MDPI, Basel, Switzerland. This article is an open access article distributed under the terms and conditions of the Creative Commons Attribution (CC BY) license (http://creativecommons.org/licenses/by/4.0/). 